\title{
The TKI Era in Chronic Leukemias
}

\author{
Danilo De Novellis ${ }^{1, *}\left(\mathbb{D}\right.$, Fabiana Cacace ${ }^{2}$, Valeria Caprioli ${ }^{2}$, William G. Wierda ${ }^{3}$, Kris M. Mahadeo ${ }^{4}$ \\ and Francesco Paolo Tambaro ${ }^{2}$
}

1 Hematology and Transplant Center, University "Hospital San Giovanni di Dio e Ruggi D'Aragona”, 84131 Salerno, Italy

2 Unità Operativa di Trapianto di Cellule Staminali Ematopoietiche e Terapie Cellulari, Azienda Ospedaliera di Rilievo Nazionale Santobono-Pausilipon, 80123 Napoli, Italy; fabianacacace@santobonopausilipon.it (F.C.); valeriacaprioli@santobonopausilipon.it (V.C.); francescopaolotambaro@santobonopausilipon.it (F.P.T.)

3 Department of Leukemia, The University of Texas MD Anderson Cancer Center, Houston, TX 77030, USA; wwierda@mdanderson.org

4 Pediatric Stem Cell Transplantation and Cellular Therapy, CARTOX Program, University of Texas at MD Anderson Cancer Center, Houston, TX 77030, USA; KMMahadeo@mdanderson.org

* Correspondence: danidenov90@gmail.com

check for updates

Citation: De Novellis, D.; Cacace, F.; Caprioli, V.; Wierda, W.G.; Mahadeo, K.M.; Tambaro, F.P. The TKI Era in Chronic Leukemias. Pharmaceutics 2021, 13, 2201. https://doi.org/ $10.3390 /$ pharmaceutics 13122201

Academic Editors:

Carmela Dell'Aversana,

Rosaria Benedetti, Federica Sarno, Wouter Leonard Megchelenbrink and Donato Cappetta

Received: 18 November 2021 Accepted: 17 December 2021 Published: 20 December 2021

Publisher's Note: MDPI stays neutra with regard to jurisdictional claims in published maps and institutional affiliations.

Copyright: (c) 2021 by the authors. Licensee MDPI, Basel, Switzerland. This article is an open access article distributed under the terms and conditions of the Creative Commons Attribution (CC BY) license (https:// creativecommons.org/licenses/by/ $4.0 /)$.

\begin{abstract}
Tyrosine kinases are proteins involved in physiological cell functions including proliferation, differentiation, and survival. However, the dysregulation of tyrosine kinase pathways occurs in malignancy, including hematological leukemias such as chronic myeloid leukemia (CML) and chronic lymphocytic leukemia (CLL). Particularly, the fusion oncoprotein BCR-ABL1 in CML and the B-cell receptor (BCR) signaling pathway in CLL are critical for leukemogenesis. Therapeutic management of these two hematological conditions was fundamentally changed in recent years, making the role of conventional chemotherapy nearly obsolete. The first, second, and third generation inhibitors (imatinib, dasatinib, nilotinib, bosutinib, and ponatinib) of BCR-ABL1 and the allosteric inhibitor asciminib showed deep genetic and molecular remission rates in CML, leading to the evaluation of treatment discontinuation in prospective trials. The irreversible BTK inhibitors (ibrutinib, acalabrutinib, zanubrutinib, tirabrutinib, and spebrutinib) covalently bind to the C481 amino acid of BTK. The reversible BTK inhibitor pirtobrutinib has a different binding site, overcoming resistance associated with mutations at C481. The PI3K inhibitors (idelalisib and duvelisib) are also effective in CLL but are currently less used because of their toxicity profiles. These tyrosine kinase inhibitors are well-tolerated, do have some associated in-class side effects that are manageable, and have remarkably improved outcomes for patients with hematologic malignancies.
\end{abstract}

Keywords: chronic myeloid leukemia (CML); chronic lymphocytic leukemia (CLL); BCR-ABL1inhibitors; BTK-inhibitors; PI3K-inhibitors; targeted therapy; treatment discontinuation

\section{Introduction}

Tyrosine kinases (TKs) are a large family of surface and intracellular signaling proteins largely conserved in multicellular organisms. Their function is in catalyzing the transfer of a phosphate group from adenosine triphosphate (ATP) to the hydroxyl group of tyrosine residues in specific substrate proteins, creating a strong covalent bond and resulting in energy transfer and signal transduction. The phosphorylation of TKs modulates their activity, promoting the recruitment of multiple downstream signal proteins. Some members are capable of autophosphorylation. This kinase family may be subclassified into transmembrane receptors and non-receptor intracellular signaling TKs [1].

Receptor TKs are transmembrane glycoproteins that physiologically interact with extracellular ligands (often growth factors), transducing the signal from the extracellular environment into the cytoplasm, promoting the dimerization of the receptor first and the autophosphorylation of tyrosine residues [2]. Many cell receptors belong to the TK family 
and are named according to their ligands (epidermal growth factor receptor (EGFR), fibroblast growth factor receptor (FGFR), nerve growth factor receptor (NGFR)), platelet-derived growth factor receptor (PDGFR), and vascular endothelial growth factor receptor (VEGFR).

Non-receptor TKs is a group of intracellular kinases that are structurally diverse and include Src, Abl, Jak, Ras, and Raf proteins that have similar activities as receptor TKs [1]. Activation of the non-receptor TKs involves aggregation and interactions among intracellular proteins and is characterized by targeted transphosphorylation [3]. Several cell functions commonly associated with cancer, such as proliferation, differentiation, survival, and metabolic impulses are mediated by TK pathways [4].

Chronic myeloid leukemia (CML) [5] and chronic lymphocytic leukemia (CLL) [6], the most common hematological malignancies in the U.S.A and Europe [7], are characterized by a dependence on kinase pathways (see below) for leukemia cell growth and survival, and as a result have been very successfully treated with TK inhibitors. Critical TKs include the fusion chimera oncoprotein BCR-ABL1 in CML [8] and the B-cell receptor (BCR) signaling pathway including Bruton Tyrosine Kinase (BTK) [9] and phosphatidylinositol 3-kinase (PI3K) in CLL [10]. The inhibition of TKs represents the prototype of targeted therapy and has proven to be a key and effective element in the treatment of these hematologic malignancies over the last twenty years. Here, we analyze and describe the role of TKs in the pathophysiology of CML and CLL, and the current tyrosine kinase inhibitor (TKi)-based treatments, both in current practice and clinical trials.

\section{Chronic Myeloid Leukemia}

\subsection{Kinase Pathways in CML}

$\mathrm{CML}$ is a clonal myeloproliferative disorder characterized by the Philadelphia (PH) chromosome, which is a genetic alteration resulting from a reciprocal translocation between chromosomes 9 and 22 [t(9;22)] [11]. The incidence rate of CML ranges from 0.6 to two cases per 100,000 individuals [6]. The PH chromosome produces the fusion oncoprotein, BCR-ABL1, which is a constitutively activated kinase responsible for the pathogenesis of CML. Three different isoforms of BCR-ABL1 (p210, p190, and p230) have been described in hematologic malignancies, which are associated with different lengths of the BCR-ABL1 fusion gene. The most common isoform in CML is p210, which is expressed by about $95 \%$ of CML patients; the p190 isoform occurs alone in 1-2\% and is co-expressed with p210 in $5-7 \%$ of patients. The p230 transcript is rare $[12,13]$.

Under physiological conditions, ABL1 is expressed during hematopoietic stem cell development; when fused with BCR, the BCR-ABL1 gene produces a constitutively active protein that loses the ability to migrate into the nucleus and is retained in the cytoplasm where it interacts with several kinases involved in leukemogenesis [14]. The different interactions of BCR-ABL1 with several pathways can be responsible for the process of leukemogenesis. Janus kinase (JAK) and Signal Transducers and Activators of Transcription (STAT) 1, 3, 5, and 6 proteins [15] have been associated with leukemogenesis in $\mathrm{PH}$-positive diseases, leading to the terminal overexpression of oncogene $c-M Y C$, which is essential for neoplastic transformation [16].

In addition, the PI3K-AKT-NF-kB-MM9 pathway is involved in CML pathogenesis. It was shown that the upregulation of this pathway, triggered by the TGF- $\beta$ inBCR-ABL1 positive hemangioblasts, leads to an enhanced secretion of soluble Kit ligand and ICAM1, promoting the activation and proliferation of CML stem cells $[17,18]$. Furthermore, PI3K is also responsible for the up-regulation of $\mathrm{Skp} 2$, which promotes the degradation of $\mathrm{p} 27$, by ubiquitination, and the consequent alteration of cycle cell regulation in CML cells [19]. Interestingly, the inhibition of PI3K-associated pathways prevents BCR-ABL1 leukemogenesis in mice, demonstrating the important role for this kinase in oncogenesis [20]. In addition, the Ras-Raf-MEK-ERK pathway, referred to as the Mitogen-Activated Protein (MAP) kinase pathway, represents one of the most ubiquitous, important, and preserved signaling pathways in multicellular organisms. After the interaction with BCR-ABL1, constitutive Ras activation is triggered, inducing the sequential phosphorylation of multiple 
Raf-Erk-Mek kinases, whose role is the recruitment of several nuclear transcription factors involved in proliferation [21]. A summary of the BCR-ABL1 pathway is shown in Figure 1.

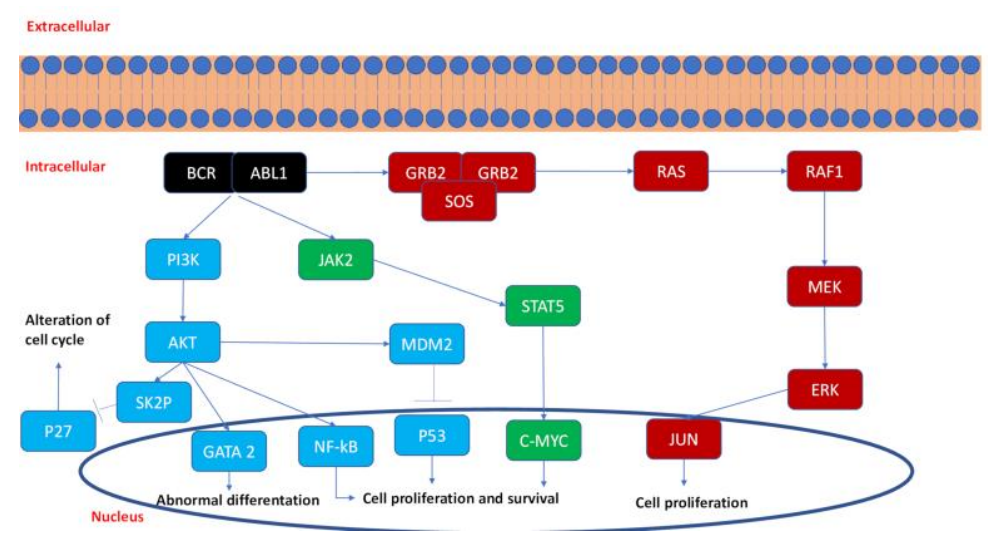

Figure 1. BCR-ABL1 signaling pathway.

The fusion oncoprotein BCR-ABL1 and downstream signaling proteins induce prosurvival, proliferation, migration and apoptosis signals in the CML cells.

Blue indicates the PI3K pathway; green is the JAK2 pathway; red is the MAP kinase pathway.

\subsection{TK Inhibition in CML}

The typical CML clinical course consists of three different phases as described by the World Health Organization (WHO) 2016 classification [22]: chronic, accelerated, and blastic phases. Most patients are diagnosed in the chronic phase, which is characterized by $<10 \%$ blast cells, and no criteria of accelerated phase (at least one of persisting or increasing white blood cell count or splenomegaly unresponsive to therapy, peripheral basophils $>20 \%$, blast cells: $10-19 \%$, platelets count $>1000 \times 10^{9} / \mathrm{L}$ uncontrolled by therapy or $<100,000 \times 10^{9} / \mathrm{L}$ unrelated to therapy, additional clonal chromosomal abnormalities). The blast phase is defined by blast cells $>20 \%$ or extramedullary involvement.

Historically, treatments for CML consisted of cytoreductive drugs, such as hydroxyurea [23] or busulfan [24]. This approach reduced and controlled peripheral white blood cell count, splenomegaly, and disease-related symptoms but was ineffective in eradicating $\mathrm{PH}^{+}$clones. Therefore, the overall survival (OS) and risk for disease progression were not improved. Interferon-alfa2a was shown to inhibit myeloid cell proliferation [25] and then was compared to conventional cytotoxic chemotherapy (busulfan or hydroxyurea) in a clinical trial. Interferon-alfa2a showed a higher rate of karyotypic responses (defined as $>33 \%$ of metaphases negative for $\mathrm{PH}$ chromosome; $30 \%$ vs. $5 \%$ ), longer median progression-free survival (PFS) (>72 vs. 45 months), and longer median OS (72 vs. 52 months) compared to cytotoxic therapy [26].

Clinical responses and outcomes for patients with CML were remarkably improved after the introduction of a small molecule TK inhibitor of BCR-ABL1, which effectively blocks all the hyperactivated pathways and results in CML cell death $[27,28]$. The first report of the small molecule inhibitor CGP57-148B was published in 1996; the proliferation rate of the granulocyte-macrophage colony-forming unit (GM-CFU) was potently decreased after exposure to the drug [29]. However, clinical testing and the development of TKi began when the compound CGP57-148B, renamed STI571 and imatinib, was evaluated in a dose-escalating phase I/II trial, which established the maximum tolerated dose as the primary end point and clinical efficacy as the secondary end point. Eighty-three patients with chronic phase CML who failed treatment with interferon received STI571 therapy. In the subgroup of patients treated with STI571 at a dose of $300 \mathrm{mg}$ or higher, 53/54 (98\%) achieved complete hematological response and 29/54 (54\%) achieved overall cytogenetic 
response, which was complete in 7/54 (13\%) of treated patients (see below for response definitions) [30,31].

Three levels of response were reported with TKi-based treatment: (1) hematologic, which was defined as the normalization of peripheral blood counts, without circulating immature elements and no-palpable spleen; (2) cytogenetic, which was defined as complete with no $\mathrm{PH}+$ detectable, partial with $\mathrm{PH}+1-35 \%$, minor with $\mathrm{PH}+36-65 \%$, minimal with $\mathrm{PH}+66-95 \%$, and no response with $\mathrm{PH}+>95 \%$; and (3) molecular, which was defined as complete molecular response (CMR) with no BCR-ABL1 transcript detectable, deep molecular response (DMR) with BCR-ABL1 transcript $<0.01 \%$ (where the molecular response 4 (MR4) is $\leq 0.01 \%$ IS, MR $4.5 \leq 0.0032 \%$ IS, and MR5 $<0.001 \%$ ), major with molecular response (MMR) BCR-ABL1 transcript $<0.1 \%$ [32].

The IRIS trial was an important randomized phase III trial that compared imatinib to interferon plus cytarabine in a population of 1106 patients with newly diagnosed chronic phase CML. The results at 12 months follow up were excellent in terms of complete cytogenetic remission (CCyR) rate $(68 \%$ vs. $7 \%$ ) and BCR-ABL1 transcript levels evaluated in the patients with cytogenetic remission, which represented at least a 1000-fold decrease in $57 \%$ vs. $24 \%$ patients treated with imatinib vs. interferon plus cytarabine, respectively [33]. After long-term treatment with imatinib, CML clones can become refractory [34]. The 5 -year update of the IRIS study showed that among a total of 553 patients [35], 35 cases $(6 \%)$ progressed to accelerated phase or blast crisis, 14 patients (3\%) had hematological relapse, and 28 patients $(5 \%)$ lost major cytogenetic response. This loss of response was probably due to point mutations in the BCR-ABL1 ATP-binding site, activation loop, or catalytic domain, which prevent imatinib from binding the oncogenic kinase. These mutations were described for the first time in 2001 [36].

The second generation TKi, dasatinib, was designed with a 100-fold increased potency in inhibiting BCR-ABL1 compared to imatinib [37]. In early phase I and II trials, dasatinib showed tolerability and efficacy in previously imatinib-treated patients with CML [38,39]. Efficacy was confirmed in the randomized phase III DASISION study where first-line treatment with dasatinib showed better results compared to imatinib after 12 (CCyR: 83\% vs. $72 \%$; MMR: $46 \%$ vs. $28 \%$ ) and 24 months treatment [40,41] (CCyR: $86 \%$ vs. $82 \%$; MMR: $64 \%$ vs. $46 \%$ ). Furthermore, the recent 5-year update of the DASASION trial confirmed the long-term efficacy of dasatinib compared to imatinib (5-year-MMR and MR 4.5: 76\% and $42 \%$ for dasatinib vs. $64 \%$ and $33 \%$ for imatinib, respectively; $p=0.0022$ and $p=0.0251$ ) [42].

Nilotinib is another second-generation TKi, which is effective against most of BCRABL1 point mutations (T315I excluded) [43]. The clinical efficacy of nilotinib was demonstrated in the randomized phase III ENESTnd trial in which different doses of nilotinib were compared to a standard dose of imatinib in newly diagnosed chronic phase CML. Outcomes for both nilotinib arms ( $300 \mathrm{mg}$ or $400 \mathrm{mg}$ twice daily) were significantly superior to imatinib at 24 months in terms of MMR ( $71 \%$ vs. $67 \%$ vs. $44 \%)$, complete molecular response ( $26 \%$ vs. $21 \%$ vs. $10 \%$ ), and progression to accelerate or blastic phase [44].

In addition, the superior efficacy of nilotinib vs. imatinib was confirmed by the 5 -year (MR 4.5: 54\% and 52\% for nilotinib $300 \mathrm{mg}$ and $400 \mathrm{mg}$ twice daily vs. $31 \%$ for imatinib) [45] and 10-year updates (MR 4.5: 61\% for both nilotinib arms vs. 39.2\% for imatinib arm) [46] of ENESTnd trial.

The threonine at position 315 of the BCR-ABL1 is important for the interaction of most TKi with BCR-ABL1. In the case of T315I mutation (threonine is replaced by isoleucine), a conformational change in BCR-ABL1 occurs that prevents the hydrogen bond between the TKi and oncogenic kinase required for the TKi to inhibit kinase activity [43]. The spectrum of reported BCR-ABL1 mutations associated to TKi resistance is shown in Table 1 [47]. 
Table 1. Spectrum of BCR-ABL1 mutations, their localization, and their relationship with TKi.

\begin{tabular}{ccc}
\hline TKI & Strong Resistance & Mild-Moderate Resistance \\
\hline Imatinib & Y253-E255-T315 & M244-L248-G250-Q252- \\
& & F317-M351-M355-F359- \\
Dasatinib & T315 & H396 \\
Nilotinib & T315 & V299-F317 \\
Bosutinib & T315-V299 & L248-Y253-E255-F359 \\
Ponatinib & & L248-G250-E255-F317 \\
Asciminib & A337-W464-P465-V468-I502 & T315-E255 \\
P-loop mutations: M244, G250, Q252, Y253, and E255; gatekeeper residue (T315 and F317); SH2 contact and C-lobe \\
(M351, F359); activation loop (H396).
\end{tabular}

Ponatinib was the first third-generation TKi specifically designed to overcome resistance from T315I mutation by its inhibitory action through the creation of an ethynyl bond [48]. The clinical efficacy of ponatinib was evaluated in the single-arm phase II PACE trial where 449 heavily pretreated patients with CML or PH+ acute lymphoblastic leukemia (ALL) were enrolled after dasatinib/nilotinib failure or with theT315I mutation. Major CCyR and MMR rates were $56 \%, 46 \%$, and $34 \%$, respectively with ponatinib treatment. Interestingly, no mutations conferring resistance to ponatinib were detected. However, serious arterial thrombotic events were observed in 9\% of patients [49]. The multicenter phase III randomized EPIC trial (ponatinib vs. imatinib in 307 treatment-naive CML) showed significantly higher rates of MMR ( $41 \%$ vs. $18 \%)$ and MR4.5, which was defined as BCR-ABL1 $\leq 0.0032 \%$ IS [50] (15\% vs. 0) at any time for patients treated on the ponatinib arm. However, $7 \%$ vs. $0.7 \%$ patients experienced severe arterial thrombotic events with ponatinib versus imatinib, leading to the early discontinuation of the trial due to concern for ponatinib toxicity [51].

Bosutinib is a potent (200 times imatinib) dual SRC/ABL kinase inhibitor that was approved for patients with CML with resistance or intolerance to imatinib, following the results of a phase I/II trial [52]. In the randomized phase III study BFORE, 536 patients with newly diagnosed chronic phase CML were enrolled 1:1 to receive bosutinib or imatinib; at 12 months, CCyR (77.2\% vs. $66.4 \% ; p=0.0075)$ and MMR $(47.2 \%$ vs. $36.9 \% ; p=0.02)$ rates were significantly higher for patients treated with bosutinib versus imatinib [53].

The ATP-binding site of BCR-ABL1 is the preferred target of kinase inhibitors, and most resistance-associated mutations occur at this site. The Specifically Targeting the ABL Myristoyl Pocket (STAMP) Asciminib (ABL001) was an innovative allosteric inhibitor that targets the BCR-ABL1 myristoyl pocket and was specifically designed to overcome all the mutations in the ATP-binding site [54]. However, rare mutations located in the myristate pocket were described, suggesting that asciminib might lose its efficacy when used in monotherapy; the association between the classic ATP-binding site inhibitors and asciminib might promote simultaneous BCR-ABL1 inhibition with combined treatment, reducing the risk of treatment resistance.

The first-in-human multicenter dose escalation phase I trial of asciminib enrolled 101 patients with CML after $\geq 2$ prior TKi or with PH+ ALL after $\geq 1$ prior TKi treatment, and it identified a recommended dose of asciminib of $40 \mathrm{mg}$ BID for CML patients. Fiftyfive patients treated $>3$ months with asciminib achieved a MMR of $23.6 \%$ (13 of 55), $43.2 \%$ (16 of 37), and $57.1 \%$ (20 of 55) at 3, 6, and 12 months, respectively [55]. The phase II trial ASC4MORE (NCT03578367) is currently ongoing to evaluate the efficacy of asciminib after imatinib in patients with chronic phase CML without deep molecular response (DMR) after $\geq 12$ months of imatinib treatment. Eighty patients were randomized to asciminib $40 \mathrm{mg}$ or $60 \mathrm{mg}$ QD plus imatinib $400 \mathrm{mg}$ QD, continued imatinib $400 \mathrm{mg}$ QD, or switch to nilotinib $300 \mathrm{mg}$ BID. The results of this study are pending [56]. The multicenter phase III ASCEMBL study compared single agent asciminib versus bosutinib in 233 patients with chronic phase CML after failure $\geq 2$ TKi. Treatment with asciminib was associated with significantly improved response compared to bosutinib in terms of 24-week MMR rate 
( $25.5 \%$ vs. $13.2 \% ; p=0.029)$ [57]. The main features of BCR-ABL inhibitors are resumed in Table 2.

Table 2. Characteristics of first line BCR-ABL inhibitors.

\begin{tabular}{|c|c|c|c|c|c|c|c|}
\hline & $\mathbf{N}$ & Clinical Trial & Trial Phase & CML Phase & TKI Dosage & Response & Bcr-AblT315I \\
\hline $\begin{array}{l}\text { Imatinib vs. } \\
\text { interferon + low-dose } \\
\text { of cytarabine }\end{array}$ & 1106 & $\begin{array}{c}\text { IRIS } \\
\text { (NCT00333840) }\end{array}$ & III & Chronic & $400 \mathrm{mg} / \mathrm{die}$ & $\begin{array}{l}\text { MCR: } 87 \% \\
\text { CCR: } 76 \%\end{array}$ & No \\
\hline $\begin{array}{l}\text { Imatinib vs. historic } \\
\text { experience }\end{array}$ & 389 & & Retrospective [58] & Accelerated & $600 \mathrm{mg} / \mathrm{die}$ & $\begin{array}{l}\text { MCR: } 49 \% \\
\text { CCR: } 43 \%\end{array}$ & no \\
\hline $\begin{array}{l}\text { Dasatinib vs. } \\
\text { imatinib }\end{array}$ & 519 & $\begin{array}{c}\text { Dasision } \\
\text { (NCT00481247) }\end{array}$ & III & Chronic & $100 \mathrm{mg} / \mathrm{die}$ & $\begin{array}{l}\text { CCR: } 83 \% \\
\text { MMR: } 46 \%\end{array}$ & no \\
\hline Dasatinib & 174 & START-A & II & R/R Accelerated & $140 \mathrm{mg} / \mathrm{die}$ & $\begin{array}{l}\text { MCR: } 39 \% \\
\text { CCR: } 32 \%\end{array}$ & no \\
\hline Dasatinib & $\begin{array}{c}109 \\
48\end{array}$ & START-C & II & $\begin{array}{c}\mathrm{R} / \mathrm{R} \text { myeloid } \\
\text { blast } \\
\mathrm{R} / \mathrm{R} \text { lymphoid } \\
\text { blast }\end{array}$ & $140 \mathrm{mg} / \mathrm{die}$ & $\begin{array}{l}\text { MCR: } 33 \% \\
\text { CCR: } 23 \% \\
\text { MCR: } 52 \% \\
\text { CCR: } 46 \%\end{array}$ & no \\
\hline Nilotinib vs. imatinib & 846 & $\begin{array}{c}\text { ENESTnd } \\
\text { (NCT00471497) }\end{array}$ & III & Chronic & $\begin{array}{l}600 \mathrm{mg} / \text { die } \\
800 \mathrm{mg} / \text { die }\end{array}$ & $\begin{array}{c}\text { CCR: } 80 \% \\
\text { MMR: } 44 \% \\
\text { CCR: } 78 \% \\
\text { MMR: } 43 \%\end{array}$ & no \\
\hline Nilotinib & 136 & & II [59] & R/R Accelerated & $800 \mathrm{mg} /$ die & $\begin{array}{l}\text { MCR: } 31 \% \\
\text { CCR: } 19 \%\end{array}$ & no \\
\hline $\begin{array}{l}\text { Bosutinib vs. } \\
\text { imatinib }\end{array}$ & 536 & $\begin{array}{c}\text { BFORE } \\
\text { (NCT02130557) }\end{array}$ & III & Chronic & $400 \mathrm{mg} / \mathrm{die}$ & $\begin{array}{l}\text { CCR: } 77 \% \\
\text { MMR: } 47 \%\end{array}$ & no \\
\hline Ponatinib & $\begin{array}{c}267 \\
83 \\
62\end{array}$ & $\begin{array}{c}\text { PACE } \\
(\text { NCT01207440) }\end{array}$ & II & $\begin{array}{c}\text { Chronic } \\
\text { Accelerated } \\
\text { Blastic }\end{array}$ & $45 \mathrm{mg} / \mathrm{die}$ & $\begin{array}{l}\text { MCR: } 56 \% \\
\text { CCR: } 46 \% \\
\text { MMR: } 34 \% \\
\text { MCR: } 39 \% \\
\text { MCR: } 23 \%\end{array}$ & yes \\
\hline
\end{tabular}

CCR, complete cytogenetic response; MCR, major cytogenetic response; MMR, major molecular response.

\subsection{TKi Treatment Discontinuation in CML}

Until recently, therapy of CML with TKi was not considered curative, and therefore, patients were treated indefinitely until intolerance or disease progression. Many recent trial results demonstrated that a proportion of patients can stop TKi treatment without experiencing a disease relapse and can potentially be cured. Nowadays, TKi treatment discontinuation is one of the most important goals for younger patients diagnosed with CML [60].

The prospective, multicenter, Stop Imatinib (STIM) trial evaluated imatinib discontinuation for 100 patients with $C M L>18$ years old who achieved CMR (defined as $>5$-log reduction in $B C R-A B L$ and $A B L$ levels and undetectable transcripts by quantitative RTPCR) for at least 2 years, after $\geq 3$ years of TKi treatment. With a median follow up of 17 months, $61 \%$ of 69 patients (at least 12 months of follow up) experienced a molecular relapse. However, all patients with molecular relapse responded to imatinib rechallenge (26 achieved a sustained CMR and 16 achieved a decrease in BCR-ABL1 transcript levels) [61]. Interestingly, the recent multicenter phase II trial DASFREE assessed treatmentfree remission (TFR) after dasatinib discontinuation in 84 patients with chronic phase CML. After 24 months discontinuation, TFR was $46 \%$, and $44 / 45$ (98\%) patients re-achieved MMR (median 2 months; range 1-4) and 43/45 (96\%) re-achieved DMR (median 3 months; range 2-18) after dasatinib rechallenge. In multivariable analysis, the duration of dasatinib treatment ( $>$ median; $p=0.005$ ), line of therapy (first-line; $p=0.0138$ ), and age ( $>65$ years; $p=0.0012$ ) were associated with 2 year-TRF [62]. In the EURO-SKI trial, the logistic progression model showed that 6 month-TRF is significantly associated with the duration of deep molecular response (DMR, defined as 10,000-fold reduction in BCR-ABL1 transcripts) with TKi, as described in Table 3 [63]. 
Table 3. Evaluation of the variables associated to 6-month major molecular response after TKI discontinuation; data from EURO-SKI trial $(N=448)$.

\begin{tabular}{ccc}
\hline Parameter & Odds Ratio (95\%CI) & $p$ Value \\
\hline Age at stop of TKI (years) & $1.9(0.95-1.26)$ & 0.21 \\
Interferon pretreatment & $2.50(1.43-4.36)$ & 0.0013 \\
Duration of interferon pretreatment (years) & $1.38(1.12-1.69)$ & 0.0022 \\
Duration of TKI treatment (years) & $1.16(1.08-1.25)$ & $<0.0001$ \\
DMR duration while receiving TKI (years) & $1.16(1.08-1.25)$ & 0.00011 \\
Time of TKI treatment before DMR (years) & $1.02(0.93-1.13)$ & 0.66 \\
\hline
\end{tabular}

In summary, current guidelines recommend TKi discontinuation for patients who have been in therapy with TKi for at least 3 years and who achieved a DMR of at least 2 years [64,65].

\section{Chronic Lymphocytic Leukemia}

\subsection{Kinase Pathways in CLL}

CLL is a clonal disorder of mature $\mathrm{B}$ lymphocytes characterized by the co-expression of CD5, CD19, CD23, and CD20 that accumulate in blood, lymph nodes, spleen, and bone marrow. The median age at diagnosis is 72 years, and most patients are initially observed without treatment [6] The B-cell receptor (BCR) signaling pathway is constitutively activated and fundamental to the pathophysiology of the leukemia cells in CLL [66]. The BCR complex consists of a surface transmembrane immunoglobulin (Ig) receptor associated with $\operatorname{Ig} \alpha(\mathrm{CD} 79 \mathrm{~A})$ and $\operatorname{Ig} \beta(\mathrm{CD} 79 \mathrm{~B})$ chains and multiple downstream intracellular signaling proteins [67]. The BCR signaling pathway is essential for B-cell survival and proliferation; the loss of one of the key intracellular downstream signaling proteins, Bruton tyrosine kinase (BTK) leads to Bruton's X-linked agammaglobulinemia (known as X-linked agammaglobulinemia (XLA)), which is a severe immunodeficiency characterized by the developmental arrest of B-cell precursors and no immunoglobulin production [68,69].

Under physiological conditions, two different signals are propagated by the BCR signaling complex: (1) a basal, constitutive survival signal, which is antigen independent and mediated through PI3K; and (2) the signal triggered by interaction of surface Ig with extracellular antigens that promotes the recruitment of downstream kinases such as LYN kinase, spleen tyrosine kinase (SYK), BTK, and PI3K. In the later signaling, upon binding of antigen and triggering of Ig signaling, LYN and SYK phosphorylate BTK, activating phospholipase C $\lambda 2$ (PLC $\lambda 2$ ), MAP kinases, AKT, and nuclear factor kappalight-chain-enhancer of activated B cells (NF-кB) [67]. BTK and PI3K were central to $\mathrm{B}$ cell signaling and therefore considered as potential targets for blocking the survival and proliferation of BCR signals with small molecule inhibitors [70,71]. However, CLL cells have different BCR pathways compared to physiological B lymphocytes: ZAP-70 is a protein that, when overexpressed in CLL cells, enhances BCR signaling, acting as an adapter protein rather than its kinase activity [72,73]. In addition, TOSO, named Fas inhibitory molecule 3 (FAIM3), is an IgM Fc receptor ( $F_{C} \mu R$ ) that is over-expressed in CLL clonal cells; the role of TOSO is not completely clear yet, but it might interact with SYK, enhancing BCR pathways and promoting apoptosis arrest [74].

A summary of BCR pathways is shown in Figure 2.

Surface B-cell receptor and down-stream signaling proteins participate in pro-survival, proliferation, migration, and apoptosis signals to the CLL cells.

Blue indicates the BTK-dependent pathway; red is the PI3K-dependent pathway; red and blue indicate common proteins. 


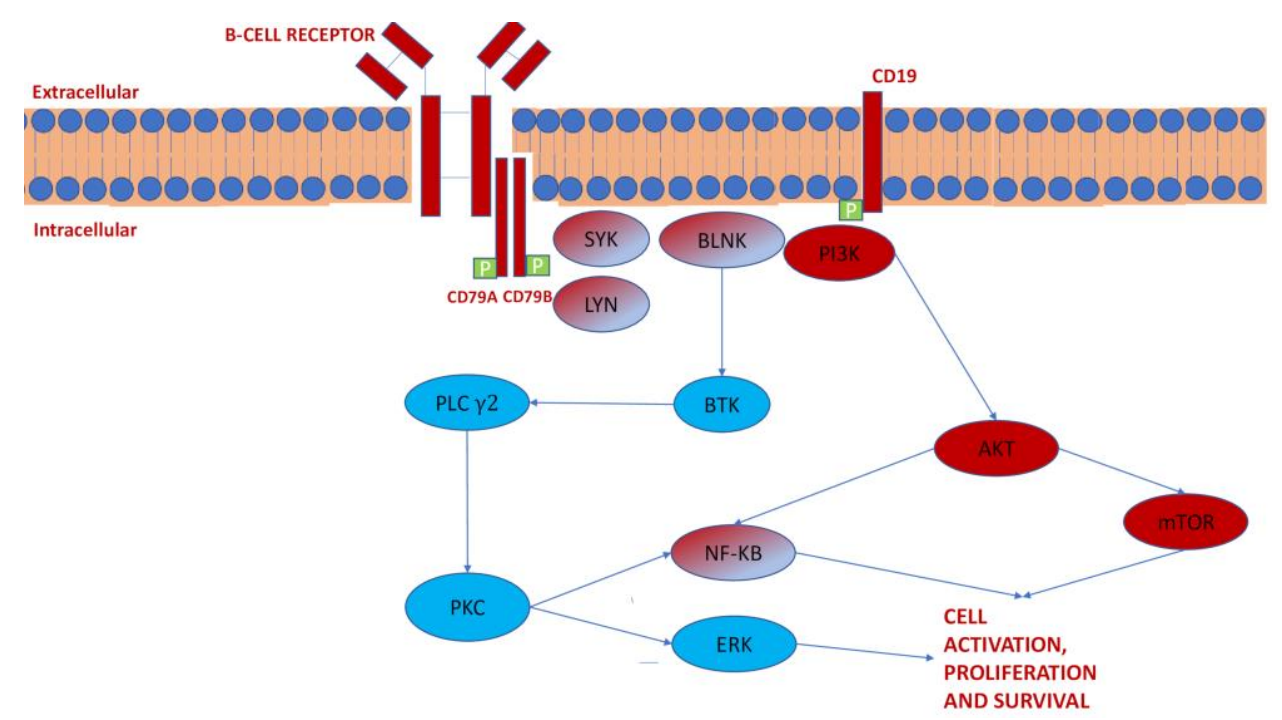

Figure 2. B-cell receptor signaling pathway.

\subsection{TK Inhibition in CLL}

Historically, first-line treatment for CLL was based on chemoimmunotherapy (CIT) consisting of CD20 monoclonal antibody (mAb), rituximab [75], or obinutuzumab [76], combined with different chemotherapeutic agents such as chlorambucil [77], bendamustine [78], or fludarabine and cyclophosphamide [79]. However, based on multiple phase III clinical trials, BTK-inhibitor-based treatment has proven superior to CIT in terms of efficacy and safety. Two different families of TKi are currently approved: BTK inhibitors (BTKi) [80] (in first-line and relapsed/refractory CLL) and PI3K inhibitors (PI3Ki) (in relapsed/refractory CLL) [81].

The mechanism of BTK inhibition may be irreversible or reversible; the currently available inhibitors are irreversible. Irreversible BTKi inactivate BTK by blocking the binding of ATP by a very stable covalent bond with the sulfhydryl group of Cys481, which is located in the BTK ATP-binding site. In contrast, reversible BTK inhibition is based on the stronger non-covalent binding of BTK, which blocks ATP binding and does not require Cys481 [82].

The family of irreversible BTKi consists of seven molecules (ibrutinib, acalabrutinib, zanubrutinib, tirabrutinib, spebrutinib, remibrutinib, and evobrutinib). Ibrutinib was approved by the FDA in 2014 for relapsed/refractory (R/R) CLL following the results of a single-arm trial in which $48 \mathrm{R} / \mathrm{R}$ patients with CLL achieved a high overall response rate (ORR; 58.3\%) and response duration (DOR; 5.6-24.2 months) [83]. The indication was expanded to include R/R del(17p) or mutated-TP53 CLL based on the RESONATE-17 trial [84,85], demonstrating a high ORR (64\%) and 24-months PFS (63\%) in 144 patients with $R / R \operatorname{del}(17 p)$ CLL. Interestingly, patients with $\operatorname{del}(17 p)$ or complex karyotype $R / R$ CLL have shorter PFS also with ibrutinib treatment compared to patients without these genetic abnormalities [86,87].

Ibrutinib was approved as a first-line treatment of CLL based on the phase III RESONATE2 trial [88], which demonstrated significantly improved PFS (median, not reached vs. 18.9 months; $p<0.001)$ and OS (24-month OS rate, $98 \%$ vs. $85 \% ; p=0.001)$ for ibrutinib compared to chlorambucil in 269 treatment-naïve (TN) patients with CLL more than 65 years old.

Other phase III trials in first-line treatment of CLL, including LLUMINATE and E1912, evaluated ibrutinib with or without CD20 mAb versus CIT. Specifically, treatment with ibrutinib plus obinutuzumab or ibrutinib plus rituximab resulted in significantly improved median PFS compared to treatment with chlorambucil-obinutuzumab in iLLUMINATE or fludarabine-cyclophosphamide-rituximab in the E1912 trial, respectively [89,90]. Additionally, the three-arm ALLIANCE trial evaluated ibrutinib with our without rituximab 
versus bendamustine plus rituximab in $\geq 65$ years patients with treatment-naïve CLL. Both the ibrutinib arms showed superior PFS with respect to bendamustine-rituximab [91].

The 6-year update of the phase III RESONATE trial showed significantly longer median PFS (44.1 vs. 8.1 months; $p<0.001)$ for ibrutinib vs. ofatumumab treatment in patients with R/R CLL [92]. Furthermore, treatment with combined ibrutinib, rituximab, and bendamustine improved median PFS compared to bendamustine plus rituximab in patients with R/R CLL in the randomized double-blind phase III HELIOS study [93] A recent update of the HELIOS trial reported a median follow up of 34.8 months and longer median PFS (not reached for ibrutinib plus bendamustine-rituximab vs. 14.3 months for bendamustine-rituximab) and higher 36-month PFS (68\% vs. $13.9 \%$, respectively) [94]. However, the value of bendamustine plus rituximab when combined with continuous ibrutinib in this regimen is debated. Continuous and indefinite treatment with ibrutinib is associated with side effects, usually mild (grade I-II), which need to be managed. For example, skin manifestations are common (up to $27 \%$ ) and consist of cutaneous rash, ecchymosis, and petechiae [86]. An increased risk of bleeding due to ibrutinib-induced platelet dysfunction is another long-term side effect [95]. In clinical trials, the rate of major bleedings (grade $\geq 3$ ), including subdural hematomas gastrointestinal and intracerebral bleedings, is reported in up to $8-10 \%$ of patients; however, this risk might be influenced by concomitant treatments with anticoagulant or antiplatelet agents [96,97]. Cardiac side effects, including atrial fibrillation (AF), hypertension, and ventricular arrhythmias are also reported during ibrutinib therapy. Notably, AF is the most frequent reason for ibrutinib discontinuation [98]. The incidence of AF increases with longer treatment period (3-7\% $<18$ months; $9-16 \% \geq 18$ months) [97].

Acalabrutinib is a second generation, more specific and selective irreversible BTKi evaluated as single agent $(n=179)$ or combined with obinutuzumab $(n=179)$ versus chlorambucil plus obinutuzumab $(n=177)$ in treatment-naïve patients CLL in the multicenter randomized phase III ELEVATE-TN trial. This trial demonstrated significantly improved PFS for both acalabrutinib-containing arms over chlorambucil plus obinutuzumab. Acalabrutinib was FDA approved in November 2019 as a first-line treatment for CLL [99]. The multicenter randomized phase III ASCEND trial also demonstrated improved PFS for acalabrutinib over the investigator's choice (idelalisib-rituximab or bendamustine-rituximab) in patients with R/R CLL [100].

An ongoing randomized, multicenter phase III non-inferiority study to evaluate ibrutinib vs. acalabrutinib for treatment of patients with high-risk cytogenetic R/R CLL (ELEVATE-RR; NCT02477696) [del(17p) or del(11q)] reported improved tolerability and toxicity for acalabrutinib with reduced incidence of all grade atrial fibrillation and noninferior efficacy for acalabrutinib versus ibrutinib and similar efficacy [101]. In addition, the ALPINE trial (NCT03734016) is a multicenter phase III trial currently evaluating zanubrutinib (irreversible BTKi) versus ibrutinib also preliminarily reporting reduced risk for all-grade atrial fibrillation for zanubrutinib over ibrutinib and with a trend for improved PFS with zanubrutinib [102].

Tirabrutinib [103], spebrutinib (NCT01732861-NCT01975610), remibrutinib [104], and evobrutinib (NCT02975349) are being evaluated in clinical trials in the setting of B-cell malignancies, including CLL, and in autoimmune diseases.

Despite very good responses and highly durable disease control achieved with BTK inhibition, some patients might develop refractory disease to irreversible BTKi and progress during treatment. Notably, resistance to irreversible BTKi has been associated with substitution of the cysteine in position 481 with a serine (C481S mutation) as the most frequent mechanism of CLL cell resistance. The cysteine residue is essential for the creation of the irreversible covalent bound between BTK and irreversible inhibitors [105]. Other mutations involving C481 have been described but are less common, including C481F, C481G, C481R, C481Y, and C481T [106,107]. Another mechanism of resistance to irreversible BTKi, although less common and BTK mutation, is the acquisition of gain of function muta- 
tions in PLC $\gamma 2$ protein (R665W and L845F), leading to autonomous BCR activity [108]. Subsequently, other mutations have been discovered and reported in Figure 3 [109].

BTKi Resistance mechanisms
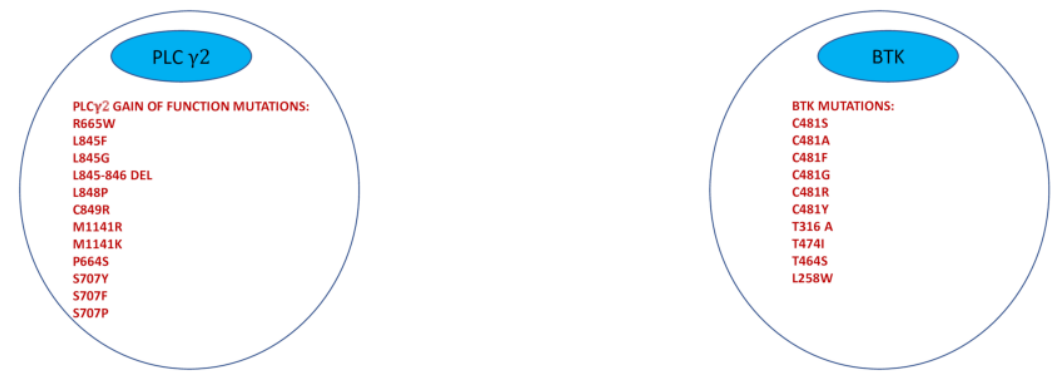

Figure 3. Spectrum of mutations related to BTKi resistance.

The reversible BTKi (pirtobrutinib, vecabrutinib, ARQ531, fenebrutinib), potentially overcomes C481 mutations by very strong non-covalent interactions (hydrogen, ionic bonds, and hydrophobic interactions) with BTK that block ATP binding and do not require C481 [82]. These other reversible BTKi showed good inhibitory activity in vitro against wild-type and mutated BTK. ARQ531 and fenebrutinib showed good results in early clinical evaluations in B-cell malignancies, including CLL. In contrast, the clinical development of vecabrutinib was discontinued because of no clinical activity in CLL [110-114]. Clinical trials of reversible BTKi are in early stages. Pirtobrutinib [115] is a reversible inhibitor being evaluated in a phase I/II study in patients with B-cell malignancies, including CLL, showing $62 \%$ ORR in the R/R CLL subgroup $(n=121)$ at the recommended dose of $200 \mathrm{mg} /$ day.

Idelalisib was the first PI3K $\delta$-inhibitor (PI3K $\delta i$ ) developed for the treatment of patients with CLL. Early phase I and II clinical trials demonstrated efficacy in terms of ORR and median PFS, showing durable responses [116,117]. However, treatment-related side effects and toxicities have been challenging with idelalisib. A high rate of treatment-related transaminitis was observed at a median of 28 days on treatment. Hepatic biopsies documented an autoimmune etiopathogenesis [118]. Lymphocytic infiltration was also seen with colitis and pneumonitis reported as treatment-related toxicities associated with idelalisib and have made use of this agent potentially challenging. Two randomized phase III trials confirmed idelalisib efficacy in CLL when combined with bendamustine-rituximab or ofatumumab, but also in these trials, excessive infection (bacterial pneumonia, pneumocystis Jirovecii pneumonia, CMV reactivation) and liver toxicity were observed $[119,120]$. Idelalisib is currently only approved for patients with R/R CLL, not in first-line treatment.

Duvelisib is a more recently developed PI $3 \mathrm{~K} \delta \mathrm{i}$, which demonstrated strong antiproliferative effects in CLL cells [121]. A phase I trial, in which patients affected by lymphoproliferative malignancies were enrolled, showed good results for duvelisib in terms of ORR. The safety profile was similar to idelalisib [122]. In the multicenter, randomized phase III DUO trial, patients with R/R CLL received duvelisib single-agent versus ofatumumab. This trial demonstrated significantly increased ORR and longer median PFS with duvelisib treatment, including in patients with high-risk cytogenetic CLL [123].

Other PI3Ki are in development. Parsaclisib is a next-generation, potent, and highly selective PI3K $\delta i$ that has been recently evaluated alone or associated in R/R B-cell malignancies, including CLL, in a phase I/II trial. Parsaclisib showed promising antitumor activity [124]. Umbralisib is an innovative PI3K $\delta / C K 1 \varepsilon$ inhibitor that showed safety and early efficacy in $51 \mathrm{R} / \mathrm{R}$ CLL patients in a phase II trial [125].

In contrast to BTKi, resistance mechanisms to PI3K $\delta \mathrm{i}$ are still poorly understood. A preclinical investigation reported increased or persistent activity of the ERK pathway, which might be involved in PI3K $\delta$ i resistance [126]. Furthermore, in mantle cell lymphoma, it was shown in vitro that a higher PIK3CA (encoding for $\mathrm{p} 110 \alpha$ )/ PIK3CD (encoding for 
$\mathrm{p} 110 \delta$ ) ratio of messenger RNA transcripts is associated to PI3K $\delta$ i resistance [127]. In addition, MYC amplification was observed as a potential resistance mechanism to PI3Ki in breast cancer models [128].

\section{Discussion}

The development and availability of targeted therapies based on tyrosine kinase inhibition has fundamentally changed the management of CML and CLL. A greater selectivity toward neoplastic cells, higher efficacy rates, oral administration, and safer toxicity profile made this therapeutic approach preferable over conventional chemotherapy. Furthermore, high cytogenetic risk diseases such as CLL with del(17p) are much more effectively treated with tyrosine kinase inhibitors.

In recent years, especially in younger patients, achieving undetectable MRD (defined as the persistence of a very low number of neoplastic cells after or during the treatment, detectable by molecular or flow cytometry analysis) $[129,130]$ has become a very important and realistic goal with TKi-based treatment, considering the desire for treatment discontinuation. Several trials in patients with CML have already shown that in predetermined conditions (CMR for at least 2 years after $\geq 3$ years of TKi treatment), the BCR-ABL1 inhibitor can be discontinued and rechallenged in case of molecular relapse. Conversely, TKi discontinuation is not yet recommended in CLL, since the remissions are not deep with TKi-based treatment (extremely rare MRD remissions), and a worse outcome was described in patients who underwent ibrutinib interruption for adverse effects [131]. Further clinical trials and follow up are recommended to identify the risk conditions for indefinite therapy in patients with CLL.

In conclusion, we highlight CML and CLL as examples of hematological malignancies in which the TKi-based approach was transformative and has remarkably improved outcomes for patients with these diseases. The discovery of new intracellular kinase pathways that may be inhibited and the approval of further tyrosine kinase inhibitors is anticipated in the future because of the intrinsic genomic instability of hematological neoplastic cells, which may develop resistance to available therapies.

Funding: This research received no external funding.

Conflicts of Interest: The authors declare no conflict of interest.

\section{References}

1. Hubbard, S.R.; Till, J.H. Protein Tyrosine Kinase Structure and Function. Annu. Rev. Biochem. 2000, 69, 373-398. [CrossRef] [PubMed]

2. Paul, M.K.; Mukhopadhyay, A.K. Tyrosine Kinase-Role and Significance in Cancer Review. 2004. Available online: www.medsci. org (accessed on 3 March 2021).

3. Heldin, C.-H. Dimerization of cell surface receptors in signal transduction. Cell 1995, 80, 213-223. [CrossRef]

4. Schlessinger, J.; Ullrich, A. Growth factor signaling by receptor tyrosine kinases. Neuron 1992, 9, 383-391. [CrossRef]

5. Höglund, M.; Sandin, F.; Simonsson, B. Epidemiology of chronic myeloid leukaemia: An update. Ann. Hematol. $2015,94,241-247$. [CrossRef]

6. Hallek, M. Chronic lymphocytic leukemia: 2020 update on diagnosis, risk stratification and treatment. Am. J. Hematol. 2019, 94, 1266-1287. [CrossRef] [PubMed]

7. Jemal, A.; Siegel, R.; Ward, E.; Murray, T.; Xu, J.; Thun, M.J. Cancer Statistics, 2007. CA Cancer J. Clin. 2007, 57, 43-66. [CrossRef]

8. Kang, Z.-J.; Liu, Y.-F.; Xu, L.-Z.; Long, Z.-J.; Huang, D.; Yang, Y.; Liu, B.; Feng, J.-X.; Pan, Y.-J.; Yan, J.-S.; et al. The Philadelphia chromosome in leukemogenesis. Chin. J. Cancer 2016, 35, 1-15. [CrossRef]

9. Woyach, J.A.; Bojnik, E.; Ruppert, A.S.; Stefanovski, M.R.; Goettl, V.M.; Smucker, K.A.; Smith, L.L.; Dubovsky, J.A.; Towns, W.H.; MacMurray, J.; et al. Bruton's tyrosine kinase (BTK) function is important to the development and expansion of chronic lymphocytic leukemia (CLL). Blood 2014, 123, 1207-1213. [CrossRef]

10. Cuní, S.; Pérez-Aciego, P.; Pérez-Chacón, G.; Vargas, J.A.; Sánchez, A.; Martín-Saavedra, F.M.; Ballester, S.; García-Marco, J.; Jordá, J.; Durántez, A. A sustained activation of PI3K/NF-kB pathway is critical for the survival of chronic lymphocytic leukemia B cells. Leukemia 2004, 18, 1391-1400. [CrossRef]

11. Rowley, J.D. A New Consistent Chromosomal Abnormality in Chronic Myelogenous Leukaemia identified by Quinacrine Fluorescence and Giemsa Staining. Nature 1973, 243, 290-293. [CrossRef] [PubMed] 
12. Arana-Trejo, R.M.; Ruíz Sánchez, E.; Ignacio-Ibarra, G.; De La Báez Fuente, E.; Garces, O.; Gómez Morales, E.; Castro Granados, M.; Ovilla Martínez, R.; Rubio-Borja, M.E.; Solís Anaya, L.; et al. BCR/ABL p210, p190 and p230 fusion genes in 250 Mexican patients with chronic myeloid leukaemia (CML). Clin. Lab. Haematol. 2002, 24, 145-150. [CrossRef]

13. Adnan-Awad, S.; Kim, D.; Hohtari, H.; Javarappa, K.K.; Brandstoetter, T.; Mayer, I.; Potdar, S.; Heckman, C.A.; Kytölä, S.; Porkka, K.; et al. Characterization of p190-Bcr-Abl chronic myeloid leukemia reveals specific signaling pathways and therapeutic targets. Leukemia 2021, 35, 1964-1975. [CrossRef] [PubMed]

14. Cilloni, D.; Saglio, G. Molecular Pathways: BCR-ABL. Clin. Cancer Res. 2012, 18, 930-937. [CrossRef]

15. Ilaria, R.L.; Van Etten, R.A. P210 and P190 Induce the Tyrosine Phosphorylation and DNA Binding Activity of Multiple Specific STAT Family Members. J. Biol. Chem. 1996, 271, 31704-31710. [CrossRef] [PubMed]

16. Sawyers, C.L. The Role of MYC in Transformation by BCR-ABL. Leuk. Lymphoma 1993, 11, 45-46. [CrossRef] [PubMed]

17. Zhu, X.; Wang, L.; Zhang, B.; Li, J.; Dou, X.; Zhao, R.C. TGF- $\beta$ 1-induced PI3K/Akt/NF- B/MMP9 signalling pathway is activated in Philadelphia chromosome-positive chronic myeloid leukaemia hemangioblasts. J. Biochem. 2011, 149, 405-414. [CrossRef] [PubMed]

18. Li, Q.; Wu, Y.; Fang, S.; Wang, L.; Qi, H.; Zhang, Y.; Zhang, J.; Li, W. BCR/ABL oncogene-induced PI3K signaling pathway leads to chronic myeloid leukemia pathogenesis by impairing immuno-modulatory function of hemangioblasts. Cancer Gene Ther. 2015, 22, 227-237. [CrossRef]

19. Andreu, E.J.; Lledó, E.; Poch, E.; Ivorra, C.; Albero, M.P.; Martínez-Climent, J.A.; Montiel-Duarte, C.; Rifón, J.; Pérez-Calvo, J.; Arbona, C.; et al. BCR-ABL Induces the Expression of Skp2 through the PI3K Pathway to Promote p27Kip1 Degradation and Proliferation of Chronic Myelogenous Leukemia Cells. Cancer Res. 2005, 65, 3264-3272. [CrossRef]

20. Kharas, M.G.; Janes, M.R.; Scarfone, V.M.; Lilly, M.B.; Knight, Z.A.; Shokat, K.M.; Fruman, D.A. Ablation of PI3K blocks BCR-ABL leukemogenesis in mice, and a dual PI3K/mTOR inhibitor prevents expansion of human BCR-ABL+ leukemia cells. J. Clin. Investig. 2008, 118, 3038-3050. [CrossRef]

21. Steelman, L.S.; Pohnert, S.C.; Shelton, J.G.; Franklin, R.A.; Bertrand, F.E.; McCubrey, J.A. JAK/STAT, Raf/MEK/ERK, PI3K/Akt and BCR-ABL in cell cycle progression and leukemogenesis. Leukemia 2004, 18, 189-218. [CrossRef]

22. Arber, D.A.; Orazi, A.; Hasserjian, R.; Thiele, J.; Borowitz, M.J.; Le Beau, M.M.; Bloomfield, C.D.; Cazzola, M.; Vardiman, J.W. The 2016 revision to the World Health Organization classification of myeloid neoplasms and acute leukemia. Blood 2016, 127, 2391-2405. [CrossRef]

23. Hehlmann, R.; Heimpel, H.; Hasford, J.; Kolb, H.J.; Pralle, H.; Hossfeld, D.K.; Queisser, W.; Loffler, H.; Hochhaus, A.; Heinze, B. Randomized comparison of interferon-alpha with busulfan and hydroxyurea in chronic myelogenous leukemia. The German CML Study Group [see comments]. Blood 1994, 84, 4064-4077. [CrossRef]

24. Chronic granulocytic leukaemia: Comparison of radiotherapy and busulphan therapy. Report of the Medical Research Council's working party for therapeutic trials in leukaemia. BMJ 1968, 1, 201-208. [CrossRef]

25. Verma, D.; Spitzer, G.; Gutterman, J.U.; Zander, A.R.; McCredie, K.B.; Dicke, K.A. Human leukocyte interferon preparation blocks granulopoietic differentiation. Blood 1979, 54, 1423-1427. [CrossRef]

26. Italian Cooperative Study Group on Chronic Myeloid Leukemia; Tura, S.; Baccarani, M.; Zuffa, E.; Russo, D.; Fanin, R.; Zaccaria, A.; Fiacchini, M. Interferon Alfa-2a as Compared with Conventional Chemotherapy for the Treatment of Chronic Myeloid Leukemia. N. Engl. J. Med. 1994, 330, 820-825. [CrossRef] [PubMed]

27. Zubay, G.; Druker, B.J.; Talpaz, M.; Resta, D.J.; Peng, B.; Buchdunger, E.; Ford, J.M.; Lydon, N.B.; Kantarjian, H.; Capdeville, R.; et al. Efficacy and safety of a specific inhibitor of the BCR-ABL tyrosine kinase in chronic myeloid leukemia: Activity of a specific inhibitor of the BCR-ABL tyrosine kinase in the blast crisis of chronic myeloid leukemia and acute lympoblastic leukemia with the Philadelphia chromosome. N. Engl. J. Med. 2001, 344, 1038-1042. [CrossRef]

28. Kennedy, J.A.; Hobbs, G. Tyrosine Kinase Inhibitors in the Treatment of Chronic-Phase CML: Strategies for Frontline Decisionmaking. Curr. Hematol. Malig. Rep. 2018, 13, 202-211. [CrossRef]

29. Druker, B.J.; Tamura, S.; Buchdunger, E.; Ohno, S.; Segal, G.M.; Fanning, S.; Zimmermann, J.; Lydon, N.B. Effects of a selective inhibitor of the Abl tyrosine kinase on the growth of Bcr-Abl positive cells. Nat. Med. 1996, 2, 561-566. [CrossRef]

30. O'Dwyer, M.E.; Druker, B.J. STI571: An inhibitor of the BCR-ABL tyrosine kinase for the treatment of chronic myelogenous leukaemia. Lancet Oncol. 2000, 1, 207-211. [CrossRef]

31. Druker, B.J.; Talpaz, M.; Resta, D.J.; Peng, B.; Buchdunger, E.; Ford, J.M.; Lydon, N.B.; Kantarjian, H.; Capdeville, R.; Ohno-Jones, S.; et al. Efficacy and Safety of a Specific Inhibitor of the BCR-ABL Tyrosine Kinase in Chronic Myeloid Leukemia. N. Engl. J. Med. 2001, 344, 1031-1037. [CrossRef]

32. Branford, S. Molecular monitoring in chronic myeloid leukemia-How low can you go? Hematology 2016, $2016,156-163$. [CrossRef] [PubMed]

33. Hughes, T.P.; Kaeda, J.; Branford, S.; Rudzki, Z.; Hochhaus, A.; Hensley, M.L.; Gathmann, I.; Bolton, A.E.; Van Hoomissen, I.C.; Goldman, J.M.; et al. Frequency of Major Molecular Responses to Imatinib or Interferon Alfa plus Cytarabine in Newly Diagnosed Chronic Myeloid Leukemia. N. Engl. J. Med. 2003, 349, 1423-1432. [CrossRef] [PubMed]

34. Litzow, M.R. Imatinib resistance: Obstacles and opportunities. Arch. Pathol. Lab. Med. 2006, 130, 669-679. [CrossRef]

35. Druker, B.J.; Guilhot, F.; O’Brien, S.G.; Gathmann, I.; Kantarjian, H.M.; Gattermann, N.; Deininger, M.W.N.; Silver, R.T.; Goldman, J.M.; Stone, R.M.; et al. Five-Year Follow-up of Patients Receiving Imatinib for Chronic Myeloid Leukemia. N. Engl. J. Med. 2006, 355, 2408-2417. [CrossRef] 
36. Milojkovic, D.; Apperley, J.F. Mechanisms of Resistance to Imatinib and Second-Generation Tyrosine Inhibitors in Chronic Myeloid Leukemia. Clin. Cancer Res. 2009, 15, 7519-7527. [CrossRef]

37. Tokarski, J.S.; Newitt, J.A.; Chang, C.Y.J.; Cheng, J.D.; Wittekind, M.; Kiefer, S.E.; Kish, K.; Lee, F.Y.F.; Borzillerri, R.; Lombardo, L.J.; et al. The Structure of Dasatinib (BMS-354825) Bound to Activated ABL Kinase Domain Elucidates Its Inhibitory Activity against Imatinib-Resistant ABL Mutants. Cancer Res. 2006, 66, 5790-5797. [CrossRef]

38. Talpaz, M.; Shah, N.P.; Kantarjian, H.; Donato, N.; Nicoll, J.; Paquette, R.; Cortes, J.; O’Brien, S.; Nicaise, C.; Bleickardt, E.; et al. Dasatinib in Imatinib-Resistant Philadelphia Chromosome-Positive Leukemias. N. Engl. J. Med. 2006, 354, 2531-2541. [CrossRef]

39. Cortes, J.; Rousselot, P.; Kim, D.-W.; Ritchie, E.; Hamerschlak, N.; Coutre, S.; Hochhaus, A.; Guilhot, F.; Saglio, G.; Apperley, J.; et al. Dasatinib induces complete hematologic and cytogenetic responses in patients with imatinib-resistant or -intolerant chronic myeloid leukemia in blast crisis. Blood 2006, 109, 3207-3213. [CrossRef]

40. Jabbour, E.; Kantarjian, H.M.; Saglio, G.; Steegmann, J.L.; Shah, N.P.; Boqué, C.; Chuah, C.; Pavlovsky, C.; Mayer, J.; Cortes, J.; et al. Early response with dasatinib or imatinib in chronic myeloid leukemia: 3-year follow-up from a randomized phase 3 trial (DASISION). Blood 2014, 123, 494-500. [CrossRef]

41. Kantarjian, H.M.; Shah, N.P.; Cortes, J.E.; Baccarani, M.; Agarwal, M.B.; Undurraga, M.S.; Wang, J.; Ipiña, J.J.K.; Kim, D.-W.; Ogura, M.; et al. Dasatinib or imatinib in newly diagnosed chronic-phase chronic myeloid leukemia: 2-year follow-up from a randomized phase 3 trial (DASISION). Blood 2012, 119, 1123-1129. [CrossRef]

42. Cortes, J.E.; Saglio, G.; Kantarjian, H.M.; Baccarani, M.; Mayer, J.; Boqué, C.; Shah, N.P.; Chuah, C.; Casanova, L.; Bradley-Garelik, B.; et al. Final 5-Year Study Results of DASISION: The Dasatinib Versus Imatinib Study in TreatmentNaïve Chronic Myeloid Leukemia Patients Trial. J. Clin. Oncol. 2016, 34, 2333-2340. [CrossRef]

43. O'Hare, T.; Eide, C.A.; Deininger, M.W.N. Bcr-Abl kinase domain mutations, drug resistance, and the road to a cure for chronic myeloid leukemia. Blood 2007, 110, 2242-2249. [CrossRef] [PubMed]

44. Kantarjian, H.M.; Hochhaus, A.; Saglio, G.; De Souza, C.; Flinn, I.W.; Stenke, L.; Goh, Y.-T.; Rosti, G.; Nakamae, H.; Gallagher, N.J.; et al. Nilotinib versus imatinib for the treatment of patients with newly diagnosed chronic phase, Philadelphia chromosome-positive, chronic myeloid leukaemia: 24-month minimum follow-up of the phase 3 randomised ENESTnd trial. Lancet Oncol. 2011, 12, 841-851. [CrossRef]

45. Hochhaus, A.; Saglio, G.; Hughes, T.; Larson, R.; Kim, D.-W.; Issaragrisil, S.; Le Coutre, P.D.; Etienne, G.; E Dorlhiac-Llacer, P.; E Clark, R.; et al. Long-term benefits and risks of frontline nilotinib vs imatinib for chronic myeloid leukemia in chronic phase: 5-year update of the randomized ENESTnd trial. Leukemia 2016, 30, 1044-1054. [CrossRef]

46. Kantarjian, H.M.; Hughes, T.P.; Larson, R.A.; Kim, D.-W.; Issaragrisil, S.; le Coutre, P.; Etienne, G.; Boquimpani, C.; Pasquini, R.; Clark, R.E.; et al. Long-term outcomes with frontline nilotinib versus imatinib in newly diagnosed chronic myeloid leukemia in chronic phase: ENESTnd 10-year analysis. Leukemia 2021, 35, 440-453. [CrossRef]

47. Braun, T.P.; Eide, C.A.; Druker, B.J. Response and Resistance to BCR-ABL1-Targeted Therapies. Cancer Cell 2020, $37,530-542$. [CrossRef] [PubMed]

48. Zhou, T.; Commodore, L.; Huang, W.-S.; Wang, Y.; Thomas, M.; Keats, J.; Xu, Q.; Rivera, V.M.; Shakespeare, W.C.; Clackson, T.; et al. Structural Mechanism of the Pan-BCR-ABL Inhibitor Ponatinib (AP24534): Lessons for Overcoming Kinase Inhibitor Resistance. Chem. Biol. Drug Des. 2010, 77, 1-11. [CrossRef]

49. Cortes, J.E.; Kim, D.-W.; Pinilla-Ibarz, J.; Le Coutre, P.; Paquette, R.; Chuah, C.; Nicolini, F.E.; Apperley, J.F.; Khoury, H.J.; Talpaz, M.; et al. A Phase 2 Trial of Ponatinib in Philadelphia Chromosome-Positive Leukemias. N. Engl. J. Med. 2013, 369, 1783-1796. [CrossRef]

50. Cross, N.; E White, H.; Müller, M.C.; Saglio, G.; Hochhaus, A. Standardized definitions of molecular response in chronic myeloid leukemia. Leukemia 2012, 26, 2172-2175. [CrossRef]

51. Lipton, J.H.; Chuah, C.; Guerci-Bresler, A.; Rosti, G.; Simpson, D.; Assouline, S.; Etienne, G.; Nicolini, F.E.; Le Coutre, P.; Clark, R.; et al. Epic: A Phase 3 Trial of Ponatinib Compared with Imatinib in Patients with Newly Diagnosed Chronic Myeloid Leukemia in Chronic Phase (CP-CML). Blood 2014, 124, 519. [CrossRef]

52. Cortes, J.; Kantarjian, H.M.; Kim, D.W.; Khoury, H.J.; Turkina, A.G.; Shen, Z.-X.; Brummendorf, T.H.; Chandy, M.; Arkin, S.; Gambacorti-Passerini, C. Efficacy and Safety of Bosutinib (SKI-606) in Patients with Chronic Phase (CP) Ph+ Chronic Myelogenous Leukemia (CML) with Resistance or Intolerance to Imatinib. Blood 2008, 112, 1098. [CrossRef]

53. Cortes, J.E.; Gambacorti-Passerini, C.; Deininger, M.W.; Mauro, M.J.; Chuah, C.; Kim, D.-W.; Dyagil, I.; Glushko, N.; Milojkovic, D.; Le Coutre, P.; et al. Bosutinib Versus Imatinib for Newly Diagnosed Chronic Myeloid Leukemia: Results From the Randomized BFORE Trial. J. Clin. Oncol. 2018, 36, 231-237. [CrossRef]

54. Schoepfer, J.; Jahnke, W.; Berellini, G.; Buonamici, S.; Cotesta, S.; Cowan-Jacob, S.W.; Dodd, S.; Drueckes, P.; Fabbro, D.; Gabriel, T.; et al. Discovery of Asciminib (ABL001), an Allosteric Inhibitor of the Tyrosine Kinase Activity of BCR-ABL1. J. Med. Chem. 2018, 61, 8120-8135. [CrossRef]

55. Hughes, F.T.P.; Goh, M.Y.-T.; Ottmann, O.G.; Minami, H.; Rea, D.; Lang, F.; Mauro, M.J.; DeAngelo, D.J.; Talpaz, M.; Hochhaus, A.; et al. Expanded Phase 1 Study of ABL001, a Potent, Allosteric Inhibitor of BCR-ABL, Reveals Significant and Durable Responses in Patients with CML-Chronic Phase with Failure of Prior TKI Therapy. Blood 2016, 128, 625. [CrossRef] 
56. Saglio, G.; Hughes, T.P.; Geissler, J.; Kapoor, S.; Longin, A.-S.; Mukherjee, A.; Cortes, J.E. Randomized, Open-Label, Multicenter, Phase 2 Study of Asciminib (ABL001) As an Add-on to Imatinib Versus Continued Imatinib Versus Switch to Nilotinib in Patients with Chronic Myeloid Leukemia in Chronic Phase Who Have Not Achieved a Deep Molecular Response with Frontline Imatinib. Blood 2019, 134, 5910. [CrossRef]

57. Hochhaus, A.; Boquimpani, C.; Rea, M.D.; Minami, M.Y.; Lomaia, E.; Voloshin, S.; Turkina, A.G.; Kim, D.-W.; Apperley, F.J.; Cortes, J.E.; et al. Efficacy and Safety Results from ASCEMBL, a Multicenter, Open-Label, Phase 3 Study of Asciminib, a Firstin-Class STAMP Inhibitor, vs. Bosutinib (BOS) in Patients (Pts) with Chronic Myeloid Leukemia in Chronic Phase (CML-CP) Previously Treated with $\geq 2$ Tyrosine Kinase Inhibitors (TKIs). Blood 2020, 136, LBA-4. [CrossRef]

58. Kantarjian, H.; Talpaz, M.; O’Brien, S.; Giles, F.; Faderl, S.; Verstovsek, S.; Garcia-Manero, G.; Shan, J.; Rios, M.B.; Champlin, R.; et al. Survival benefit with imatinib mesylate therapy in patients with accelerated-phase chronic myelogenous leukemia-Comparison with historic experience. Cancer 2005, 103, 2099-2108. [CrossRef] [PubMed]

59. Giles, F.J.; Abruzzese, E.; Rosti, G.; Kim, N.-W.; Bhatia, R.; Bosly, A.; Goldberg, S.; Kam, G.L.; Jagasia, M.; Mendrek, W.; et al. Nilotinib is active in chronic and accelerated phase chronic myeloid leukemia following failure of imatinib and dasatinib therapy. Leukemia 2010, 24, 1299-1301. [CrossRef] [PubMed]

60. Ross, D.M.; Branford, S.; Seymour, J.F.; Schwarer, A.P.; Arthur, C.; Yeung, D.T.; Dang, P.; Goyne, J.M.; Slader, C.; Filshie, R.J.; et al. Safety and efficacy of imatinib cessation for CML patients with stable undetectable minimal residual disease: Results from the TWISTER study. Blood 2013, 122, 515-522. [CrossRef] [PubMed]

61. Mahon, F.-X.; Réa, D.; Guilhot, J.; Guilhot, F.; Huguet, F.; Nicolini, F.; Legros, L.; Charbonnier, A.; Guerci, A.; Varet, B.; et al. Discontinuation of imatinib in patients with chronic myeloid leukaemia who have maintained complete molecular remission for at least 2 years: The prospective, multicentre Stop Imatinib (STIM) trial. Lancet Oncol. 2010, 11, 1029-1035. [CrossRef]

62. Shah, N.P.; García-Gutiérrez, V.; Jiménez-Velasco, A.; Larson, S.; Saussele, S.; Rea, D.; Mahon, F.-X.; Levy, M.Y.; Gómez-Casares, M.T.; Pane, F.; et al. Dasatinib discontinuation in patients with chronic-phase chronic myeloid leukemia and stable deep molecular response: The DASFREE study. Leuk. Lymphoma 2020, 61, 650-659. [CrossRef]

63. Saussele, S.; Richter, J.; Guilhot, J.; Gruber, F.X.; Hjorth-Hansen, H.; Almeida, A.; Janssen, J.J.W.M.; Mayer, J.; Koskenvesa, P.; Panayiotidis, P.; et al. Discontinuation of tyrosine kinase inhibitor therapy in chronic myeloid leukaemia (EURO-SKI): A prespecified interim analysis of a prospective, multicentre, non-randomised, trial. Lancet Oncol. 2018, 19, 747-757. [CrossRef]

64. Hochhaus, A.; Baccarani, M.; Silver, R.T.; Schiffer, C.; Apperley, J.F.; Cervantes, F.; Clark, R.E.; Cortes, J.E.; Deininger, M.W.; Guilhot, F; et al. European LeukemiaNet 2020 recommendations for treating chronic myeloid leukemia. Leukemia 2020, 34, 966-984. [CrossRef] [PubMed]

65. Shah, N.P. NCCN Guidelines Updates: Discontinuing TKI Therapy in the Treatment of Chronic Myeloid Leukemia. J. Natl. Compr. Cancer Netw. 2019, 17, 611-613.

66. Herishanu, Y.; Pérez-Galán, P.; Liu, D.; Biancotto, A.; Pittaluga, S.; Vire, B.; Gibellini, F.; Njuguna, N.; Lee, E.; Stennett, L.; et al. The lymph node microenvironment promotes B-cell receptor signaling, NF- $\mathrm{kB}$ activation, and tumor proliferation in chronic lymphocytic leukemia. Blood 2011, 117, 563-574. [CrossRef]

67. Dal Porto, J.M.; Gauld, S.B.; Merrell, K.T.; Mills, D.; Pugh-Bernard, A.E.; Cambier, J. B cell antigen receptor signaling 101. Mol. Immunol. 2004, 41, 599-613. [CrossRef]

68. Vihinen, M.; Mattsson, P.T.; Smith, C.I. Bruton tyrosine kinase BTK in X-linked agammaglobulinemia XLA. Front. Biosci. 2000, 5, 917-928. [CrossRef] [PubMed]

69. Crofford, L.J.; Nyhoff, L.E.; Sheehan, J.H.; Kendall, P.L. The role of Bruton's tyrosine kinase in autoimmunity and implications for therapy. Expert Rev. Clin. Immunol. 2016, 12, 763-773. [CrossRef]

70. Cheng, S.; Ma, J.; Guo, A.; Lu, P.; Leonard, J.P.; Coleman, M.P.; Liu, M.; Buggy, J.J.; Furman, R.R.; Wang, Y.L. BTK inhibition targets in vivo CLL proliferation through its effects on B-cell receptor signaling activity. Leukemia 2013, 28, 649-657. [CrossRef]

71. Wiestner, A. Emerging role of kinase-targeted strategies in chronic lymphocytic leukemia. Hematology 2012, 2012, 88-96. [CrossRef] [PubMed]

72. Woyach, J.A.; Johnson, A.J.; Byrd, J.C. The B-cell receptor signaling pathway as a therapeutic target in CLL. Blood 2012, 120, 1175-1184. [CrossRef]

73. Chen, L.; Huynh, L.; Apgar, J.; Tang, L.; Rassenti, L.; Weiss, A.; Kipps, T.J. ZAP-70 enhances IgM signaling independent of its kinase activity in chronic lymphocytic leukemia. Blood 2008, 111, 2685-2692. [CrossRef]

74. Zhang, Y.-R.; Lyu, P.; Xiong, W.-J.; Liu, X.-X.; Liu, H.-M.; Cui, R.; Wang, Q.; Chen, W.-M.; Qiu, L.-G.; Yi, S.-H. TOSO interacts with SYK and enhances BCR pathway activation in chronic lymphocytic leukemia. Chin. Med. J. 2020, 133, 2090-2097. [CrossRef]

75. Jaglowski, S.M.; Byrd, J.C. Rituximab in Chronic Lymphocytic Leukemia. Semin. Hematol. 2010, 47, 156-169. [CrossRef] [PubMed]

76. Cartron, G.; De Guibert, S.; Dilhuydy, M.-S.; Morschhauser, F.; Leblond, V.; Dupuis, J.; Mahe, B.; Bouabdallah, R.; Lei, G.; Wenger, M.; et al. Obinutuzumab (GA101) in relapsed/refractory chronic lymphocytic leukemia: Final data from the phase $1 / 2$ GAUGUIN study. Blood 2014, 124, 2196-2202. [CrossRef] [PubMed]

77. Richards, S.; Clarke, M.; Wheatley, K.; Peto, R. Chemotherapeutic Options in Chronic Lymphocytic Leukemia: A Meta-analysis of the Randomized Trials. J. Natl. Cancer Inst. 1999, 91, 861-868. [CrossRef]

78. Niederle, N.; Megdenberg, D.; Balleisen, L.; Heit, W.; Knauf, W.; Weiß, J.; Freier, W.; Hinke, A.; Ibach, S.; Eimermacher, H. Bendamustine compared to fludarabine as second-line treatment in chronic lymphocytic leukemia. Ann. Hematol. 2013, 92, 653-660. [CrossRef] [PubMed] 
79. Tam, C.S.; O’Brien, S.; Wierda, W.; Kantarjian, H.; Wen, S.; Do, K.-A.; Thomas, D.A.; Cortes, J.; Lerner, S.; Keating, M.J. Long-term results of the fludarabine, cyclophosphamide, and rituximab regimen as initial therapy of chronic lymphocytic leukemia. Blood 2008, 112, 975-980. [CrossRef]

80. Herman, S.E.M.; Gordon, A.L.; Hertlein, E.; Ramanunni, A.; Zhang, X.; Jaglowski, S.; Flynn, J.; Jones, J.; Blum, K.A.; Buggy, J.J.; et al. Bruton tyrosine kinase represents a promising therapeutic target for treatment of chronic lymphocytic leukemia and is effectively targeted by PCI-32765. Blood 2011, 117, 6287-6296. [CrossRef] [PubMed]

81. Herman, S.E.M.; Gordon, A.L.; Wagner, A.J.; Heerema, N.A.; Zhao, W.; Flynn, J.M.; Jones, J.; Andritsos, L.; Puri, K.D.; Lannutti, B.J.; et al. Phosphatidylinositol 3-kinase- $\delta$ inhibitor CAL-101 shows promising preclinical activity in chronic lymphocytic leukemia by antagonizing intrinsic and extrinsic cellular survival signals. Blood 2010, 116, 2078-2088. [CrossRef] [PubMed]

82. Liang, C.; Tian, D.; Ren, X.; Ding, S.; Jia, M.; Xin, M.; Thareja, S. The development of Bruton's tyrosine kinase (BTK) inhibitors from 2012 to 2017: A mini-review. Eur. J. Med. Chem. 2018, 151, 315-326. [CrossRef] [PubMed]

83. De Claro, R.A.; McGinn, K.M.; Verdun, N.; Lee, S.-L.; Chiu, H.-J.; Saber, H.; Brower, M.E.; Chang, C.G.; Pfuma, E.; Habtemariam, B.; et al. FDA Approval: Ibrutinib for Patients with Previously Treated Mantle Cell Lymphoma and Previously Treated Chronic Lymphocytic Leukemia. Clin. Cancer Res. 2015, 21, 3586-3590. [CrossRef]

84. O'Brien, S.; Jones, J.A.; Coutre, S.E.; Mato, A.R.; Hillmen, P.; Tam, C.; Österborg, A.; Siddiqi, T.; Thirman, M.J.; Furman, R.R.; et al. Ibrutinib for patients with relapsed or refractory chronic lymphocytic leukaemia with 17p deletion (RESONATE-17): A phase 2, open-label, multicentre study. Lancet Oncol. 2016, 17, 768-778. [CrossRef]

85. Zenz, T.; Mohr, J.; Edelmann, J.; Sarno, A.; Hoth, P.; Heuberger, M.; Helfrich, H.; Mertens, D.; Döhner, H.; Stilgenbauer, S. Treatment resistance in chronic lymphocytic leukemia-the role of the p53 pathway. Leuk. Lymphoma 2009, 50, 510-513. [CrossRef] [PubMed]

86. Byrd, J.C.; Furman, R.R.; Coutre, S.E.; Flinn, I.W.; Burger, J.A.; Blum, K.A.; Grant, B.; Sharman, J.P.; Coleman, M.; Wierda, W.G.; et al. Targeting BTK with Ibrutinib in Relapsed Chronic Lymphocytic Leukemia. N. Engl. J. Med. 2013, 369, 32-42. [CrossRef]

87. Thompson, P.A.; O’Brien, S.M.; Wierda, W.G.; Ferrajoli, A.; Stingo, F.C.; Smith, S.C.; Burger, J.A.; Estrov, Z.; Jain, N.; Kantarjian, H.M.; et al. Complex karyotype is a stronger predictor than del(17p) for an inferior outcome in relapsed or refractory chronic lymphocytic leukemia patients treated with ibrutinib-based regimens. Cancer 2015, 121, 3612-3621. [CrossRef]

88. Burger, J.A.; Tedeschi, A.; Barr, P.M.; Robak, T.; Owen, C.; Ghia, P.; Bairey, O.; Hillmen, P.; Bartlett, N.L.; Li, J.; et al. Ibrutinib as Initial Therapy for Patients with Chronic Lymphocytic Leukemia. N. Engl. J. Med. 2015, 373, 2425-2437. [CrossRef]

89. Moreno, C.; Greil, R.; Demirkan, F.; Tedeschi, A.; Anz, B.; Larratt, L.; Šimkovič, M.; Samoilova, O.; Novak, J.; Ben-Yehuda, D.; et al. Ibrutinib plus obinutuzumab versus chlorambucil plus obinutuzumab in first-line treatment of chronic lymphocytic leukaemia (iLLUMINATE): A multicentre, randomised, open-label, phase 3 trial. Lancet Oncol. 2018, 20, 43-56. [CrossRef]

90. Shanafelt, T.D.; Wang, X.V.; Kay, N.E.; Hanson, C.A.; O’Brien, S.; Barrientos, J.; Jelinek, D.F.; Braggio, E.; Leis, J.F.; Zhang, C.C.; et al. Ibrutinib-Rituximab or Chemoimmunotherapy for Chronic Lymphocytic Leukemia. N. Engl. J. Med. 2019, 381, $432-443$. [CrossRef]

91. Woyach, J.A.; Ruppert, A.S.; Heerema, N.A.; Zhao, W.; Booth, A.M.; Ding, W.; Bartlett, N.L.; Brander, D.M.; Barr, P.M.; Rogers, K.A.; et al. Ibrutinib Regimens versus Chemoimmunotherapy in Older Patients with Untreated CLL. N. Engl. J. Med. 2018, 379, 2517-2528. [CrossRef]

92. Munir, T.; Brown, J.R.; O’Brien, S.; Barrientos, J.C.; Barr, P.M.; Reddy, N.M.; Coutre, S.; Tam, C.S.; Mulligan, S.P.; Jaeger, U.; et al. Final analysis from RESONATE: Up to six years of follow-up on ibrutinib in patients with previously treated chronic lymphocytic leukemia or small lymphocytic lymphoma. Am. J. Hematol. 2019, 94, 1353-1363. [CrossRef]

93. Chanan-Khan, A.; Cramer, P.; Demirkan, F.; Fraser, G.; Silva, R.S.; Grosicki, S.; Pristupa, A.; Janssens, A.; Mayer, J.; Bartlett, N.L.; et al. Ibrutinib combined with bendamustine and rituximab compared with placebo, bendamustine, and rituximab for previously treated chronic lymphocytic leukaemia or small lymphocytic lymphoma (HELIOS): A randomised, double-blind, phase 3 study. Lancet Oncol. 2015, 17, 200-211. [CrossRef]

94. Fraser, G.; Cramer, P.; Demirkan, F.; Silva, R.S.; Grosicki, S.; Pristupa, A.; Janssens, A.; Mayer, J.; Bartlett, N.; Dilhuydy, M.-S.; et al. Updated results from the phase 3 HELIOS study of ibrutinib, bendamustine, and rituximab in relapsed chronic lymphocytic leukemia/small lymphocytic lymphoma. Leukemia 2018, 33, 969-980. [CrossRef]

95. Atkinson, B.T.; Ellmeier, W.; Watson, S.P. Tec regulates platelet activation by GPVI in the absence of Btk. Blood 2003, 102, 3592-3599. [CrossRef]

96. Byrd, J.C.; Furman, R.R.; Coutre, S.E.; Burger, J.A.; Blum, K.A.; Coleman, M.; Wierda, W.G.; Jones, J.A.; Zhao, W.; Heerema, N.A.; et al. Three-year follow-up of treatment-naïve and previously treated patients with CLL and SLL receiving single-agent ibrutinib. Blood 2015, 125, 2497-2506. [CrossRef] [PubMed]

97. Paydas, S. Management of adverse effects/toxicity of ibrutinib. Crit. Rev. Oncol. 2019, 136, 56-63. [CrossRef]

98. Mato, A.R.; Nabhan, C.; Thompson, M.C.; Lamanna, N.; Brander, D.M.; Hill, B.; Howlett, C.; Skarbnik, A.; Cheson, B.D.; Zent, C.; et al. Toxicities and outcomes of 616 ibrutinib-treated patients in the United States: A real-world analysis. Haematologica 2018, 103, 874-879. [CrossRef]

99. Sharman, J.P.; Banerji, V.; Fogliatto, L.M.; Herishanu, Y.; Munir, T.; Walewska, R.; Follows, G.; Karlsson, K.; Ghia, P.; Corbett, G.; et al. ELEVATE TN: Phase 3 Study of Acalabrutinib Combined with Obinutuzumab (O) or Alone Vs O Plus Chlorambucil (Clb) in Patients (Pts) with Treatment-Naive Chronic Lymphocytic Leukemia (CLL). Blood 2019, 134, 31. [CrossRef] 
100. Ghia, P.; Pluta, A.; Wach, M.; Lysak, D.; Kozak, T.; Šimkovič, M.; Kaplan, P.; Kraychok, I.; Illes, A.; de la Serna, J.; et al. ASCEND: Phase III, Randomized Trial of Acalabrutinib Versus Idelalisib Plus Rituximab or Bendamustine Plus Rituximab in Relapsed or Refractory Chronic Lymphocytic Leukemia. J. Clin. Oncol. 2020, 38, 2849-2861. [CrossRef] [PubMed]

101. Byrd, J.C.; Hillmen, P.; Ghia, P.; Kater, A.P.; Chanan-Khan, A.; Furman, R.R.; O’Brien, S.; Yenerel, M.N.; Illés, A.; Kay, N.; et al. Acalabrutinib Versus Ibrutinib in Previously Treated Chronic Lymphocytic Leukemia: Results of the First Randomized Phase III Trial. J. Clin. Oncol. 2021, 39, 3441-3452. [CrossRef] [PubMed]

102. Hillmen, P.; Brown, J.R.; Eichhorst, B.F.; Lamanna, N.; O’Brien, S.M.; Qiu, L.; Salmi, T.; Hilger, J.; Wu, K.; Cohen, A.; et al. ALPINE: Zanubrutinib versus ibrutinib in relapsed/refractory chronic lymphocytic leukemia/small lymphocytic lymphoma. Future Oncol. 2020, 16, 517-523. [CrossRef] [PubMed]

103. Danilov, A.V.; Herbaux, C.; Walter, H.S.; Hillmen, P.; Rule, S.A.; Kio, E.A.; Karlin, L.; Dyer, M.J.; Mitra, S.S.; Yi, P.C.; et al. Phase Ib Study of Tirabrutinib in Combination with Idelalisib or Entospletinib in Previously Treated Chronic Lymphocytic Leukemia. Clin. Cancer Res. 2020, 26, 2810-2818. [CrossRef]

104. Kaul, M.; End, P.; Cabanski, M.; Schuhler, C.; Jakab, A.; Kistowska, M.; Kinhikar, A.; Maiolica, A.; Sinn, A.; Fuhr, R.; et al. Remibrutinib (LOU064): A selective potent oral BTK inhibitor with promising clinical safety and pharmacodynamics in a randomized phase I trial. Clin. Transl. Sci. 2021, 14, 1756-1768. [CrossRef]

105. Sharma, S.; Galanina, N.; Guo, A.; Lee, J.; Kadri, S.; Van Slambrouck, C.; Long, B.; Wang, W.; Ming, M.; Furtado, L.V.; et al. Identification of a structurally novel BTK mutation that drives ibrutinib resistance in CLL. Oncotarget 2016, 7, 68833-68841. [CrossRef] [PubMed]

106. Estupiñán, H.Y.; Wang, Q.; Berglöf, A.; Schaafsma, G.C.P.; Shi, Y.; Zhou, L.; Mohammad, D.K.; Yu, L.; Vihinen, M.; Zain, R.; et al. BTK gatekeeper residue variation combined with cysteine 481 substitution causes super-resistance to irreversible inhibitors acalabrutinib, ibrutinib and zanubrutinib. Leukemia 2021, 35, 1317-1329. [CrossRef]

107. Hamasy, A.; Wang, Q.; Blomberg, K.E.M.; Mohammad, D.K.; Yu, L.; Vihinen, M.; Berglöf, A.; Smith, C.I.E. Substitution scanning identifies a novel, catalytically active ibrutinib-resistant BTK cysteine 481 to threonine (C481T) variant. Leukemia 2017, 31, 177-185. [CrossRef] [PubMed]

108. Woyach, J.A.; Furman, R.R.; Liu, T.-M.; Ozer, H.G.; Zapatka, M.; Ruppert, A.S.; Xue, L.; Li, D.H.-H.; Steggerda, S.M.; Versele, M.; et al. Resistance Mechanisms for the Bruton's Tyrosine Kinase Inhibitor Ibrutinib. N. Engl. J. Med. 2014, 370, 2286-2294. [CrossRef]

109. Smith, C.I.E.; Burger, J.A. Resistance Mutations to BTK Inhibitors Originate From the NF-kB but Not From the PI3K-RAS-MAPK Arm of the B Cell Receptor Signaling Pathway. Front. Immunol. 2021, 12, 1-14. [CrossRef] [PubMed]

110. Reiff, S.D.; Mantel, R.; Smith, L.L.; Greene, J.T.; Muhowski, E.M.; Fabian, C.A.; Goettl, V.M.; Tran, M.; Harrington, B.K.; Rogers, K.A.; et al. The BTK Inhibitor ARQ 531 Targets Ibrutinib-Resistant CLL and Richter Transformation. Cancer Discov. 2018, 8, 1300-1315. [CrossRef]

111. Chan, P.; Yu, J.; Chinn, L.; Prohn, M.; Huisman, J.; Matzuka, B.; Hanley, W.; Tuckwell, K.; Quartino, A. Population Pharmacokinetics, Efficacy Exposure-response Analysis, and Model-based Meta-analysis of Fenebrutinib in Subjects with Rheumatoid Arthritis. Pharm. Res. 2020, 37, 1-13. [CrossRef]

112. Fabian, C.A.; Reiff, S.D.; Guinn, D.; Neuman, L.; Fox, J.A.; Wilson, W.; Byrd, J.C.; Woyach, J.A.; Johnson, A.J. Abstract 1207: SNS-062 Demonstrates Efficacy in Chronic Lymphocytic Leukemia In Vitro and Inhibits C481S Mutated Bruton Tyrosine Kinase; American Association for Cancer Research: Philadelphia, PA, USA, 2017.

113. Woyach, J.; Stephens, D.D.M.; Flinn, I.W.; Bhat, S.A.; Savage, R.E.; Chai, F.; Eathiraj, S.; Granlund, L.; Szuszkiewicz, L.A.; Schwartz, B.; et al. Final Results of Phase 1, Dose Escalation Study Evaluating ARQ 531 in Patients with Relapsed or Refractory B-Cell Lymphoid Malignancies. Blood 2019, 134, 4298. [CrossRef]

114. Byrd, J.C.; Smith, S.; Wagner-Johnston, N.; Sharman, J.; Chen, A.I.; Advani, R.; Augustson, B.; Marlton, P.; Commerford, S.R.; Okrah, K.; et al. First-in-human phase 1 study of the BTK inhibitor GDC-0853 in relapsed or refractory B-cell NHL and CLL. Oncotarget 2018, 9, 13023-13035. [CrossRef]

115. Mato, A.R.; Shah, N.N.; Jurczak, W.; Cheah, C.Y.; Pagel, J.M.; Woyach, J.A.; Fakhri, B.; Eyre, T.A.; Lamanna, N.; Patel, M.R.; et al. Pirtobrutinib in relapsed or refractory B-cell malignancies (BRUIN): A phase 1/2 study. Lancet 2021, 397, 892-901. [CrossRef]

116. Barrientos, J.C.; Furman, R.R.; Leonard, J.; Flinn, I.; Rai, K.R.; De Vos, S.; Schreeder, M.T.; Wagner-Johnston, N.D.; Sharman, J.P.; Boyd, T.E.; et al. Update on a phase I study of the selective PI3K $\delta$ inhibitor idelalisib (GS-1101) in combination with rituximab and/or bendamustine in patients with relapsed or refractory CLL. J. Clin. Oncol. 2013, 31, 7017. [CrossRef]

117. O’Brien, S.M.; Lamanna, N.; Kipps, T.J.; Flinn, I.; Zelenetz, A.D.; Burger, J.A.; Keating, M.; Mitra, S.; Holes, L.; Yu, A.S.; et al. A phase 2 study of idelalisib plus rituximab in treatment-naïve older patients with chronic lymphocytic leukemia. Blood 2015, 126, 2686-2694. [CrossRef]

118. Lampson, B.L.; Kasar, S.N.; Matos, T.R.; Morgan, E.A.; Rassenti, L.; Davids, M.S.; Fisher, D.C.; Freedman, A.S.; Jacobson, C.A.; Armand, P.; et al. Idelalisib given front-line for treatment of chronic lymphocytic leukemia causes frequent immune-mediated hepatotoxicity. Blood 2016, 128, 195-203. [CrossRef] [PubMed]

119. Jones, J.A.; Robak, T.; Brown, J.R.; Awan, F.T.; Badoux, X.; Coutre, S.; Loscertales, J.; Taylor, K.; Vandenberghe, E.; Wach, M.; et al. Efficacy and safety of idelalisib in combination with ofatumumab for previously treated chronic lymphocytic leukaemia: An open-label, randomised phase 3 trial. Lancet Haematol. 2017, 4, e114-e126. [CrossRef] 
120. Zelenetz, A.D.; Barrientos, J.C.; Brown, J.R.; Coiffier, B.; Delgado, J.; Egyed, M.; Ghia, P.; Illés, P.Á.; Jurczak, W.; Marlton, P.; et al. Idelalisib or placebo in combination with bendamustine and rituximab in patients with relapsed or refractory chronic lymphocytic leukaemia: Interim results from a phase 3, randomised, double-blind, placebo-controlled trial. Lancet Oncol. 2017, 18, 297-311. [CrossRef]

121. Vangapandu, H.V.; Jain, N.; Gandhi, V. Duvelisib: A phosphoinositide-3 kinase $\delta / \gamma$ inhibitor for chronic lymphocytic leukemia. Expert Opin. Investig. Drugs 2017, 26, 625-632. [CrossRef]

122. Flinn, I.W.; O’Brien, S.; Kahl, B.; Patel, M.; Oki, Y.; Foss, F.F.; Porcu, P.; Jones, J.; Burger, J.A.; Jain, N.; et al. Duvelisib, a novel oral dual inhibitor of PI3K- $\delta, \gamma$, is clinically active in advanced hematologic malignancies. Blood 2018, 131, 877-887. [CrossRef] [PubMed]

123. Flinn, I.W.; Hillmen, P.; Montillo, M.; Nagy, Z.; Illés, A.; Etienne, G.; Delgado, J.; Kuss, B.J.; Tam, C.S.; Gasztonyi, Z.; et al. The phase 3 DUO trial: Duvelisib vs ofatumumab in relapsed and refractory CLL/SLL. Blood 2018, 132, 2446-2455. [CrossRef]

124. Forero-Torres, A.; Ramchandren, R.; Yacoub, A.; Wertheim, M.S.; Edenfield, W.J.; Caimi, P.; Gutierrez, M.; Akard, L.; Escobar, C.; Call, J.; et al. Parsaclisib, a potent and highly selective PI3K $\delta$ inhibitor, in patients with relapsed or refractory B-cell malignancies. Blood 2019, 133, 1742-1752. [CrossRef]

125. Mato, A.R.; Ghosh, N.; Schuster, S.J.; Lamanna, N.; Pagel, J.M.; Flinn, I.W.; Barrientos, J.C.; Rai, K.R.; Reeves, J.A.; Cheson, B.D.; et al. Phase 2 study of the safety and efficacy of umbralisib in patients with CLL who are intolerant to BTK or PI3K $\delta$ inhibitor therapy. Blood 2021, 137, 2817-2826. [CrossRef] [PubMed]

126. Murali, I.; Kasar, S.; McWilliams, E.M.; Itchaki, G.; Tyekucheva, S.; Livitz, D.; Leshchiner, I.; Dong, S.; Fernandes, S.M.; Getz, G.; et al. Activating MAPK Pathway Mutations Mediate Primary Resistance to PI3K Inhibitors in Chronic Lymphocytic Leukemia (CLL). Blood 2018, 132, 587. [CrossRef]

127. Iyengar, S.; Clear, A.; Bödör, C.; Maharaj, L.; Lee, A.; Calaminici, M.; Matthews, J.; Iqbal, S.; Auer, R.; Gribben, J.; et al. P110 $\alpha$ mediated constitutive PI3K signaling limits the efficacy of p1108-selective inhibition in mantle cell lymphoma, particularly with multiple relapse. Blood 2013, 121, 2274-2284. [CrossRef]

128. Woyach, J.A.; Johnson, A.J. Targeted therapies in CLL: Mechanisms of resistance and strategies for management. Blood 2015, 126, 471-477. [CrossRef]

129. Fürstenau, M.; De Silva, N.; Eichhorst, B.; Hallek, M. Minimal Residual Disease Assessment in CLL: Ready for Use in Clinical Routine? HemaSphere 2019, 3, e287. [CrossRef] [PubMed]

130. Izzo, B.; Gottardi, E.M.; Errichiello, S.; Daraio, F.; Baratè, C.; Galimberti, S. Monitoring Chronic Myeloid Leukemia: How Molecular Tools May Drive Therapeutic Approaches. Front. Oncol. 2019, 9, 833. [CrossRef]

131. Maddocks, K.J.; Ruppert, A.S.; Lozanski, G.; Heerema, N.A.; Zhao, W.; Abruzzo, L.V.; Lozanski, A.; Davis, M.; Gordon, A.L.; Smith, L.L.; et al. Etiology of Ibrutinib Therapy Discontinuation and Outcomes in Patients with Chronic Lymphocytic Leukemia. JAMA Oncol. 2015, 1, 80-87. [CrossRef] 